SCHMIDT, D; CARON, BO; VALERA, O; MEIRA, D; FONTANA, DC; ZANATTA, TP; WERNER, CJ; BREZOLIN, P. 2018. Base temperature, thermal time and phyllochron of escarole cultivation. Horticultura Brasileira 36: 466-472. DOI - http://dx.doi.org/10.1590/S0102-053620180407

\title{
Base temperature, thermal time and phyllochron of escarole cultivation
}

\author{
Denise Schmidt ${ }^{1}$; Braulio O Caron ${ }^{1}$; Oscar Valera ${ }^{2}$; Daniela Meira1; Daniele C Fontana ${ }^{1}$; Thais P \\ Zanatta $^{1}$; Carla J Werner'; Patricia Brezolin ${ }^{1}$
}

${ }^{1}$ Universidade Federal de Santa Maria (UFSM), Frederico Westphalen-RS, Brasil; denise@ufsm.br; otomarcaron@yahoo.com. br; dmdanielameira94@gmail.com; daani_fontana@hotmail.com; thais_2zanatta@hotmail.com; carli.werner@hotmail.com; patriciabrezolin@hotmail.com; ${ }^{2}$ Instituto Tecnológico Superior de Zongolica, Zongolica-Veracruz, México; oscar.valera@live.com.mx

\begin{abstract}
The objective of this study was to determine the base temperature of escarole and to apply in the phenological analysis of crop during four growing periods. The study was carried out with escarole (Chicorium endivia) 'Escarola Lisa' cultivar, at the Federal University of Santa Maria, campus Frederico Westphalen-RS. The experiment was performed in a randomized block design with four sowing periods (P1: 2/15/2015; P2: 04/29/2015, P3: 07/22/2015, P4: 10/16/2015) and 10 replicates, each replicate being one plant. The evaluations consisted of counting the number of leaves, performed three times a week after transplanting date until the harvesting point. To determine the base temperature, the following methods were used: standard deviation in degree-days $\left(\mathrm{SD}_{\mathrm{gd}}\right)$, standard deviation in days $\left(\mathrm{SD}_{\mathrm{d}}\right)$, coefficient of variation in degree-days $\left(\mathrm{CV}_{\mathrm{gd}}\right)$, coefficient of variation in days $\left(\mathrm{CV}_{\mathrm{d}}\right)$, regression coefficient $(\mathrm{RC})$ and $\mathrm{X}$-intercept. The base temperature for emission of two successive leaves in the escarole is $4.7^{\circ} \mathrm{C}$, obtained by values of 4.0 and $5.5^{\circ} \mathrm{C}$, observed in the SDgd and $\mathrm{RC}$ methods. For two leaves emission, the temperature between 16.6 and $27.8^{\circ} \mathrm{C}$ day leaf ${ }^{-1}$ is necessary.
\end{abstract}

Keywords: Chicorium endivia, phenology, degree-days, leaf emission.

\begin{abstract}
RESUMO
Temperatura base, soma térmica e filocrono no cultivo de escarola

O objetivo deste trabalho foi determinar a temperatura base da chicória e aplicá-la na análise fenológica da cultura, durante quatro períodos de cultivo. O trabalho foi realizado com a cultura da chicória (Chicorium endivia) cultivar Escarola Lisa, na Universidade Federal de Santa Maria, campus Frederico Westphalen-RS. O experimento foi conduzido em delineamento de blocos ao acaso com quatro períodos de cultivo (P1: 15/2/2015; P2: 29/04/2015, P3: 22/07/2015, P4: 16/10/2015) em 10 repetições, com uma planta por repetição. As avaliações consistiram da contagem do número de folhas, realizada três vezes por semana após transplante até o ponto de colheita. Para determinação de temperatura base utilizaram-se os métodos desvio padrão em graus dias ( $\left.\mathrm{DP}_{\mathrm{gd}}\right)$, desvio padrão em dias $\left(\mathrm{DP}_{\mathrm{d}}\right)$, coeficiente da variação em graus dias $\left(\mathrm{CV}_{\mathrm{gd}}\right)$, coeficiente de variação em dias $\left(\mathrm{CV}_{\mathrm{d}}\right)$, coeficiente de regressão $(\mathrm{CR}), \mathrm{X}$-intercepto. Desta forma, a temperatura base para emissão de duas folhas sucessivas na escarola é de $4,7^{\circ} \mathrm{C}$, obtida através dos valores de 4,0 e $5,5^{\circ} \mathrm{C}$, observados nos métodos $\mathrm{DP}_{\mathrm{gd}}$ e CR. Para a emissão de duas folhas é necessário entre 16,6 e $27,8^{\circ} \mathrm{C}$ dia folha ${ }^{-1}$.
\end{abstract}

Palavras-chave: Chicorium endivia, fenologia, graus-dia, emissão de folha.

\section{Received on September 5, 2017; accepted on June 21, 2018}

$\mathrm{E}_{\mathrm{s}}^{\mathrm{s}}$ scarole (Chicorium endivia) is a specie of Asteraceae family (Filgueira, 2000), constituting the most popular group of leafy vegetables in Brazil, together with lettuce, cabbage, rocket and kale (Feltrim et al., 2008). Its growing and consumption in greater scale occurs in the South and Southeast regions of Brazil, mainly in the winter months. It may be consumed in the form of salads and sauces, and, regardless of the consumption form, it has large amounts of vitamins and nutrients, as well as functional components (Feltrim et al., 2008).

According to Caron et al. (2007), the relationships among climatic conditions and agricultural production are complex because they directly affect the growth and development of plants under different forms at different vegetative stages of crops. For escarole crop, for example, it is desirable to have warmer diurnal and mild night temperatures, which is optimal for plant development, in the range of 14 to $16^{\circ} \mathrm{C}$ (Reghin et al., 2007). However, the ideal conditions for the development of the escarole crop are still not well elucidated, due to the scarcity of studies that quantify base temperature for development of this leafy vegetable.
The plant's development is given as thermal units accumulated above a base temperature, whereas below this temperature the development of plants is negligible or null (Souza et al., 2015). Through thermal accumulation, also known as degree-days or thermal sum, excellent correlations have been obtained with the crop cycle duration, or with the stages of phenological development of a given cultivar (Volpe et al., 2002).

The air temperature is the main element that determines the growth rate of the crop, changing the period of growth necessary to reach the harvest 
point (Beckmann-Cavalcante, 2009). It also affects the speed of chemical reactions and internal processes of solutes transport and the normal plant development (Taiz et al., 2017).

The lettuce (Lactuca sativa), belonging to the same botanical family of escarole, presents a requirement of short days during the vegetative phase, and long days, so that the flowering occurs; when there is an association between long days and high temperatures, it accelerates flowering (Diamante et al., 2012). However, its growing has limitations, mainly due to its sensitivity to adverse conditions of temperature, humidity and rain (Gomes et al., 2005).

The ability of a species to adapt to a wide range of environments is considered of great interest to producers (Figueiredo et al., 2004), so it is of fundamental importance to know the minimum temperature for plant development. Thus, hypotheses were formulated: 1) base temperature for escarole allow development and growth in four seasons?; 2) thermal accumulated time in hot seasons may decrease cycle period? The objective of this study was to determine base temperature and thermal accumulation time for escarole from emergence to harvest stage.

\section{MATERIAL AND METHODS}

\section{Vegetal material and experiment conditions}

The present study was carried out at Federal University of Santa Maria (UFSM) Campus Frederico WestphalenRS (273' $\mathrm{S}, 53^{\circ} 42^{\prime} \mathrm{O}, 490$ meters altitude). The cultivar Escarola Lisa (Chicorium endivia) was used during the four experimental seasons. According to the classification of Köppen, the climate is type 3, subtropical humid, $2100 \mathrm{~mm}$ average annual rainfall and $19.1^{\circ} \mathrm{C}$ average annual temperature (Alvares et al., 2014). The soil is classified as typical Latosol Red alumino-ferric (Embrapa, 2013).

Soil was prepared through plowing and sorting, and fertilized according to the interpretation of soil analysis, by the Fertilization and Liming Manual for
Rio Grande do Sul and Santa Catarina (CQFSRS/SC, 2004).

Seedlings were transplanted with two or three leaves, 25 days after sowing. Seedlings were grown in beds $1.2 \mathrm{~m}$ wide and planted at $0.2 \times 0.25$ $\mathrm{m}$ spacing. For irrigation, reference evapotranspiration (ETo) was calculated according to Penman (1948) and adapted by Monteith (1965). Thus, daily water requirement was calculated by multiplying ETo by crop coefficient (Kc) (Allen et al., 1998), necessary irrigation being made available through the drip irrigation system.

The experiment was conducted in randomized blocks design, with 10 replicates, each replicate consisting of one plant. The treatments consisted of 4 growing periods: P1) February 15, 2015; P2) April 4, 2015; P3) July 7, 2015 and P4) October 16, 2015. Growing periods were analyzed according to seasons of the year, defined in south Brazil. The evaluations consisted of counting the number of leaves (NF), considering the emission of a fully expanded leaf $(>5 \mathrm{~cm})$, performed three times a week after transplant until the plant reaches 50 leaves, considered the harvest point.

The meteorological data (rainfall, solar radiation, temperatures) were obtained through the automatic meteorological station of Frederico Westphalen-RS (INMET, Frederico Westphalen, A854), located 200 meters distant from the experiment.

\section{Thermal time}

In order to determine the lower base temperature $(\mathrm{Tb})$, the daily thermal time ( $\mathrm{Tt}$ ) was estimated according to the equation proposed by Arnold (1960):

$T t=(T a-T b)$

where $\mathrm{Tt}=$ thermal time, $\mathrm{Ta}=$ average air temperature, $\mathrm{Tb}=$ lower base temperature. The results are expressed in growing degree-days (GDD, ${ }^{\circ} \mathrm{C}$ day), where $1 \mathrm{GDD}$ is equal to $1^{\circ} \mathrm{C}$ above $\mathrm{Tb}$.

The thermal time was calculated from the emission of the first true leaf, and the accumulated thermal time (Tta) was obtained from the daily thermal time, expressed in ${ }^{\circ} \mathrm{C}$ day:

$T t a=\sum T t$

Where $\mathrm{Tta}=$ accumulated thermal time, $\mathrm{Tt}=$ daily thermal time.
The lower base temperature $(\mathrm{Tb})$ is defined as the daily thermal time above a lower base temperature (Rosa et al., 2011), which was determined by the methods below.

Methods for calculation of lower Tb

For the estimation of the lower base temperature $(\mathrm{Tb})$, different methodologies proposed by Arnold, (1960) were used:

\section{Standard deviation in degree-days}

The standard deviation method in degree-days $\left(\mathrm{SD}_{\mathrm{gd}}\right)$ considers $\mathrm{Tb}$ as result from the smallest standard deviation of the thermal time obtained using a series of $\mathrm{Tb}$. The $\mathrm{SD}_{\mathrm{gd}}$ is calculated using the equation:

$$
S D_{g d}=\sqrt{\frac{\sum_{i=1}^{n}\left(G D_{i}-G D a\right)^{2}}{n-1}}
$$

Where $\mathrm{SD}_{\mathrm{gd}}=$ standard deviation in degree-days, $\mathrm{GD}_{\mathrm{i}}=$ accumulated degreedays in the $\mathrm{i}$-th growing period using a series of $\mathrm{Tb}, \mathrm{GD}_{\mathrm{a}}=$ average of degreedays accumulated in all $i$-th transplant periods, $\mathrm{n}=$ number of growing periods.

\section{Standard deviation in days}

In the method of standard deviation in days $\left(\mathrm{SD}_{\mathrm{d}}\right), \mathrm{Tb}$ is resulted from the smaller standard deviation among different growing periods, according to the equation:

$$
S D_{d}=\frac{S D_{g d}}{\bar{x}-T b}
$$

Where $\mathrm{SD}_{\mathrm{d}}=$ standard deviation in days, $\mathrm{SD}_{\mathrm{gd}}=$ standard deviation in degreedays using a series of $\mathrm{Tb}, \bar{x}=$ average air temperature $\left({ }^{\circ} \mathrm{C}\right)$ of all $i$ times, $\mathrm{T}_{\mathrm{b}}=$ lower base temperature $\left({ }^{\circ} \mathrm{C}\right)$.

\section{days}

Coefficient of variation in degree-

The coefficient of variation in degree-days $\left(\mathrm{CV}_{\mathrm{gd}}\right)$ method considers as $\mathrm{Tb}$ the one that presents the lowest coefficient of variation in relation to degree-days accumulated in the development phase in question. $\mathrm{CV}_{\mathrm{gd}}$ is obtained from the formula:

$C V_{g d}=\frac{S D_{g d}}{G D a} \cdot 100$

Where $\mathrm{CV}_{\mathrm{gd}}=$ coefficient of variation in degree-days, $\mathrm{SD}_{\mathrm{gd}}=$ standard deviation in degree-days using a series of $\mathrm{Tb}, \mathrm{GD}_{\mathrm{a}}$ $=$ average of degree-days accumulated in all i-th transplant periods.

\section{Coefficient of variation in days}

The coefficient of variation in days 
$\left(\mathrm{CV}_{\mathrm{d}}\right)$ determines $\mathrm{Tb}$ in the lowest coefficient of variation obtained from the relation between the standard deviation in days $\left(\mathrm{SD}_{\mathrm{d}}\right)$ and a number of days in the development phase, so the $\mathrm{CV}_{\mathrm{d}}$ is determined from the equation:

$$
C V_{d}=\frac{S D_{d}}{\bar{x} d} \cdot 100
$$

Where $\mathrm{CV}_{\mathrm{d}}=$ coefficient of variation and days $(\%), \mathrm{SD}_{\mathrm{d}}=$ standard deviation in days, $\bar{x}_{\mathrm{d}}=$ number of days in development phase.

\section{Regression coefficient}

The regression coefficient (RC) method is based on linear relationship between average air temperature during plant development $\left(\mathrm{T}_{\mathrm{x}}\right)$ and degreedays (GDi) accumulated during the development phase. Considering the following:

$$
G D_{i}=a T \bar{x}+b
$$

Where $a=$ coefficient of linear regression, $\mathrm{T}_{\bar{x}}=$ average air temperature during plant development, $b=$ linear coefficient.

\section{$X$-intercept}

This method is based on linear relationship between average air temperature $\left(\mathrm{T}_{\mathrm{a}}\right)$ during the development phase and relative development (DR) values, according to the equation:

$D R=a T a+b$;

Where

$D_{r}=\frac{100}{n}$

Where $\mathrm{a}=$ coefficient of linear regression, $\mathrm{T}_{\mathrm{a}}=$ average air temperature, $\mathrm{b}=$ linear coefficient.

In the $\mathrm{X}$-intercept, the $\mathrm{Tb}$ value is given when $\mathrm{DR}=0$, obtained by extending the linear regression between the DR as function of Ta, such that $\mathrm{Tb}=-\mathrm{b} / \mathrm{a}$.

Determination of lower base temperature and phyllochron

$\mathrm{Tb}$ was determined by mean $\mathrm{Tb}$ values obtained from different methods used. With the obtained Tb value, the phyllochron was estimated. For this, linear regression was performed between number of leaves (NL) and accumulated thermal time (Tta, ${ }^{\circ} \mathrm{C}$ day) for each period. Thus, the phyllochron value was determined by inverse of angular coefficient linear regression between Tta and number of leaves.

\section{Statistical analysis}

The values of cycle duration in days, thermal time and phyllochron were submitted to variance analysis by the $\mathrm{F}$ test, afterwards mean comparison by the Tukey test at $5 \%$ probability was performed.

\section{RESULTS AND DISCUSSION}

During the four growing periods, the air temperature showed variations as observed in Table 1. The average temperatures used for the estimation of $\mathrm{Tb}$ ranged between 16.2 and $22.9^{\circ} \mathrm{C}$, with absolute temperatures between 4.0 and $33.7^{\circ} \mathrm{C}$. This exposure to different air temperatures is essential in studies that use thermal time as a measure of biological time on growth and development parameters.

The calculated base temperature values showed variation among methods (Figure 1). In the SDgd method, a base temperature of $4.0^{\circ} \mathrm{C}$ was observed, however, for SDd, CVgd and CVd, a temperature around $2.5^{\circ} \mathrm{C}$ was observed. In the RC and $\mathrm{X}$-intercept methods, base temperatures of 5.5 and $3.0^{\circ} \mathrm{C}$, respectively, were observed. Differences in lower base temperatures observed in six methods were probably due to variations in air temperature shown during the escarole development phase during four growing periods. The differences among methods are justified by the specificity of each evaluation method (Table 1).

The lower base temperatures estimated ranged between 2.5 and $5.5^{\circ} \mathrm{C}$. This variation is smaller than that found by Martins et al. (2012), who estimated base temperature for olive trees, and observed temperatures from 4 to $14^{\circ} \mathrm{C}$ using other methods for its calculation. Fagundes et al. (2010), using standard deviation in days, regression coefficient and $\mathrm{X}$-intercept methods observed base temperatures of 12.9 to $14^{\circ} \mathrm{C}$ and 5.5 to $9.3^{\circ} \mathrm{C}$ for two different development phases of Aspilia montevidensis, also observing variations among the used methods.

However, the used methods proved to be feasible, since as already mentioned in the SDd, CVgd and CVd methods, calculated $\mathrm{Tb}$ values were similar. In addition, the smaller variance among thermal time of each period, which was used for $\mathrm{Tb}$ estimative by different methods (except for X-intercept method), was given when the base temperature of $4^{\circ} \mathrm{C}$ (Figure 1G) was used, being similar to the value obtained by SDgd method.

For the RC method, the linear regression equation showed an angular coefficient of 0.16 (Figure 1F). Fagundes et al. (2010), using the same method, obtained coefficients of 0.19 and 0.44 for two development subperiods, being that values closer to zero represent a more accurate $\mathrm{Tb}$ value, as observed in the study. As shown in Figure $1 \mathrm{D}$, the linear regression used in the $\mathrm{X}$-intercept method showed a coefficient of determination $\left(\mathrm{R}^{2}\right)$ of $84 \%$, being considered statistically high.

Considering the above, none of the methods used could be discarded, however, the estimated $\mathrm{Tb}$ values of 2.5 and $3.0^{\circ} \mathrm{C}$ were below the absolute minimum $\left(4.0^{\circ} \mathrm{C}\right)$, that is, they are not

Table 1. Maximum and minimum air temperatures $\left({ }^{\circ} \mathrm{C}\right)$ recorded at four growing periods of Chicorium endivia. Frederico Westphalen, UFSM, 2015.

\begin{tabular}{lccccc}
\hline $\begin{array}{l}\text { Growing } \\
\text { period }\end{array}$ & $\begin{array}{c}\text { Absolute } \\
\text { minimum }\end{array}$ & $\begin{array}{c}\text { Absolute } \\
\text { maximum }\end{array}$ & $\begin{array}{c}\text { Average } \\
\text { minimum }\end{array}$ & $\begin{array}{c}\text { Average } \\
\text { maximum }\end{array}$ & Average \\
\hline P1 & 12.8 & 33.4 & 18.6 & 29.2 & 22.9 \\
P2 & 7.6 & 30.2 & 14.6 & 22.4 & 16.7 \\
P3 & 4.0 & 32.1 & 12.2 & 21.8 & 16.2 \\
P4 & 9.4 & 33.7 & 17.3 & 25.1 & 21.1 \\
\hline
\end{tabular}

P1= February 15, 2015 - May 4, 2015; P2=April 29, 2015 - October 7, 2015; P3= July 22, 2015 - September 21, 2015; P4= October 16, 2015 - December 21, 2015. 


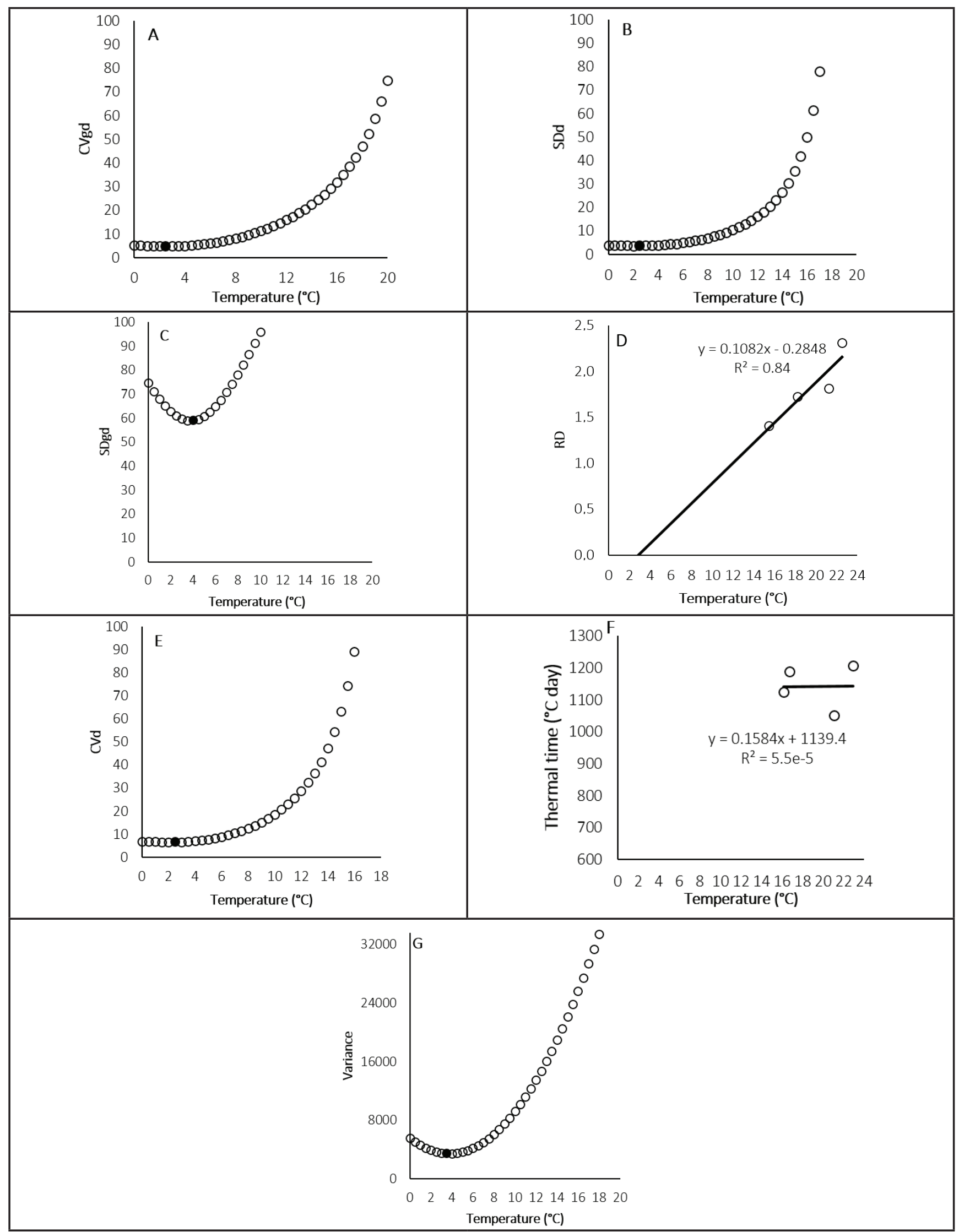

Figure 1. Lower base temperature of Chicorium endivia estimated by coefficient of variation in degree-days (CVdg) (A); standard deviation in days (SDd) (B); standard deviation in degree-days (SDdg) (C); relative development (RD) (D); coefficient of variation in days (CVd) (E); linear regression coefficient $(\mathrm{RC})(\mathrm{F})$; methods and variance between accumulated thermal time and different base temperatures $(\mathrm{G})$. Black color point indicate the value of the base temperature. Frederico Westphalen, UFSM, 2015. 
between the temperatures registered. The methods used are statistical methods, so there may be differences between physiological $\mathrm{Tb}$ and statistically determined $\mathrm{Tb}$. According to Moreno et al. (2014), it is important to maintain the classification of estimated $\mathrm{Tb}$ within range of temperatures registered, since it is a determinant factor in the estimated Tb.

Therefore, the average between 4.0 and $5.5^{\circ} \mathrm{C}$ was used, obtained in SDgd and RC methods, respectively, resulting in a $\mathrm{Tb}$ of $4.7^{\circ} \mathrm{C}$. There are no registers of a minimum temperature that might affect escarole development, but comparing it with other leafy vegetables, such as lettuce, estimated temperatures were of $4^{\circ} \mathrm{C}$ in Japan (Madariaga \& Knott, 1951) and $10^{\circ} \mathrm{C}$ in Campinas-SP (Brunini et al., 1976).

The variance analysis showed a

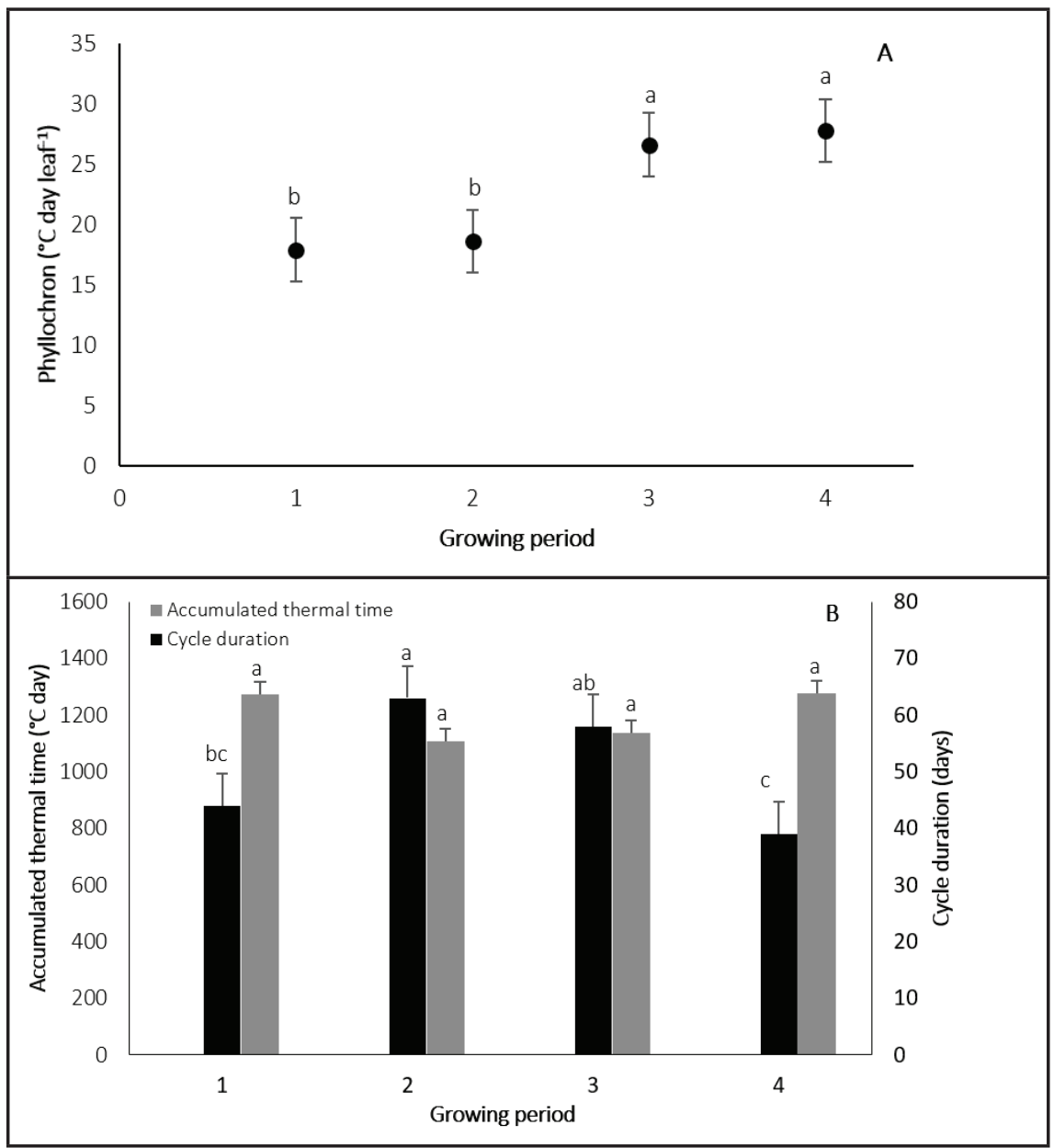

Figure 2. Phyllochron of Chicorium endivia (A) and cycle length in days and accumulated thermal time (B) from emergence to harvest point in four growing periods. $\mathrm{P} 1=$ February 15 , 2015 - May 4, 2015; P2=April 29, 2015 - October 7, 2015; P3= July 22, 2015 - September 21, 2015; P4= October 16, 2015 - December 21, 2015. Frederico Westphalen, UFSM, 2015. during $\mathrm{P} 2$ and P3 (Table 1). According to Sá \& Reghin (2008), minimum temperatures of 8 and $9^{\circ} \mathrm{C}$ may slow escarole development, consequently, as observed in this study, it was necessary to increase the number of days to reach the harvest point that is not desired for leafy vegetables. In this context, Feltrim et al. (2006) reported that lower amplitudes may provide better escarole development, justifying results observed for growing periods. The results observed in this study, for four growing periods, were contrary to those shown by Reghin et al. (2006), which reported a good development under mild temperatures showing cycles of 86 and 83 days. However, temperatures of 22.9 and $22.4^{\circ} \mathrm{C}$ as shown in $\mathrm{P} 1$ and $\mathrm{P} 4$ periods conditioned faster development, which may result in gains, since shorter cycles might reduce expenses in agronomic management, in addition to ensuring better sale prices in the market.

For phyllochron, values of 16.6 and $17.9^{\circ} \mathrm{C}$ day leaf ${ }^{-1}$ were observed in $\mathrm{P} 1$ and $\mathrm{P} 2$ growing periods, differing statistically from $\mathrm{P} 3$ and $\mathrm{P} 4$, which showed values of 26.5 and $27.8^{\circ} \mathrm{C}$ day leaf ${ }^{-1}$, respectively (Figure 2 ). The higher phyllochron values indicate a lower leaf emission rate (Figure 3), since they require higher thermal time $\left({ }^{\circ} \mathrm{C}\right.$ day leaf ${ }^{1}$ ) for its growth (Mendonça et al., 2012), and consequently lower phyllochron values indicate lower amount of thermal time to emit a leaf (Martins et al., 2012), that is, fast development.

Therefore, phyllochron results reflect a faster development for the P1 and P2, however, this result was not observed, probably due to the differences in air temperature, occurred in growth period. Beckmann-Cavalcante et al. (2009) cite that air temperature is a main variable that affects a plant growth rate. In this context, Dalmago et al. (2013), in the phyllochron estimate for canola, observed 23.5 to $59.0^{\circ} \mathrm{C}$ day leaf $^{-1}$, reaching this variation at several air temperature regimes during day and night, such as low temperatures.

The differences in phyllochron values observed in this study were influenced by variations in air temperature (Table 


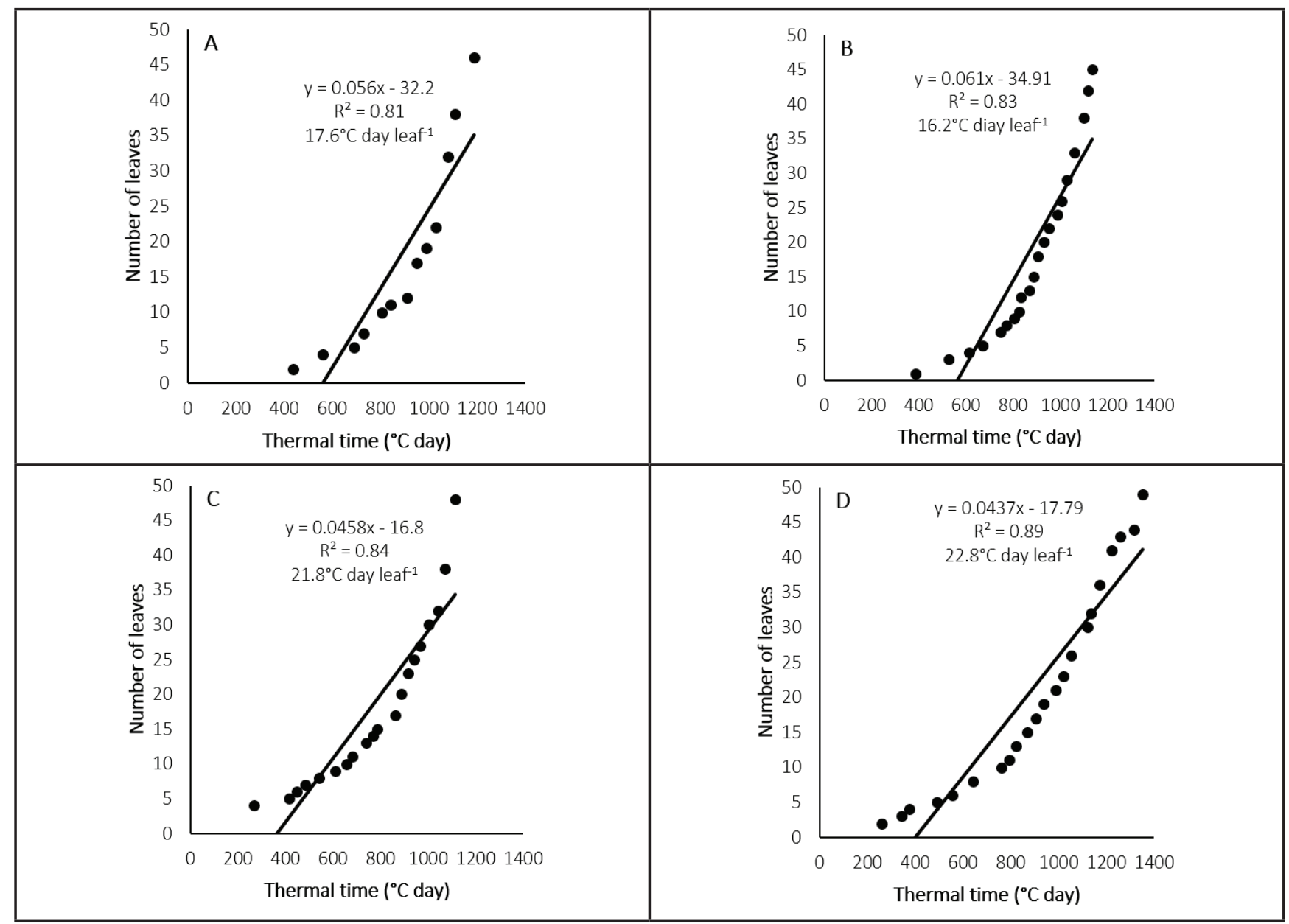

Figure 3. Linear regression between number of leaves and accumulated thermal time $\left({ }^{\circ} \mathrm{C}\right.$ day) for the calculation of the phyllochron $\left({ }^{\circ} \mathrm{C}\right.$ day leaf ${ }^{-1}$ ) of Chicorium endivia at growing periods, being P1= February 15, 2015 - May 4, 2015; P2= April 29, 2015 - October 7, 2015 ; P3= July 22, 2015 - September 21, 2015; P4= October 16, 2015 - December 21, 2015. Values are of one repetition. Frederico Westphalen, UFSM, 2015.

1). According to Birch et al. (1998), differences in phyllochron values may be related to the temperature oscillation in short periods of time. During P2, the temperatures decreased at the end of the period, observing minimum temperatures of 20 to $10^{\circ} \mathrm{C}$ and maximum of 30 to $20^{\circ} \mathrm{C}$, registering minimum and maximum peaks of 7.2 and $30.2^{\circ} \mathrm{C}$, respectively. For $\mathrm{P} 4$, from beginning to end of cycle there was an increase in temperatures, observing that the minimums were 10 to $20^{\circ} \mathrm{C}$ and the maximum of 30 to $25^{\circ} \mathrm{C}$, with minimum peaks of $9.4^{\circ} \mathrm{C}$ and maximum of $33.7^{\circ} \mathrm{C}$. In both $\mathrm{P} 2$ and $\mathrm{P} 4$ the temperature variation was higher, compared to $\mathrm{P} 1$ and P3, whereas in P3 the lowest temperatures were recorded (Table 1), however, they remained more constant.

Temperature variation explains phyllochron values obtained in this study. Since it was assumed that leaf emission has a linear behavior in relation to average air temperature, during the entire development phase, and probably temperature requirements were different during each stage after issuing a new leaf. According to Itoh \& Sano (2006), leaf emission rate might vary after a determinate number of leaves, because minimum temperature required for leaf emission varies with the position and order of leaf in question.

Thus, in general, the plants respond distinctly, where minimum and maximum temperatures may have caused an imbalance in the emission of leaves. According to Cocco et al. (2016), the occurrence of maximum temperatures during plant development influences the phyllochron variation in the crop cycle, because leaf emission is dependent of temperature. Regardless of species, temperature fluctuations (Itoh \& Shimizu, 2012), as well as ontogenic changes (Pržulj \& Momčilović, 2013) during the development period, may strongly influence the phyllochron.

For each period, it was possible to observe in the simple linear regression between number of leaves and accumulated thermal time, coefficients of determination $\left(\mathrm{R}^{2}\right)$ above $81 \%$ (Figure 3), showing high correlation, fact that proves that linear regression method is efficient to phyllochron estimative (Cocco et al., 2016).

Since the objective is to have a tool to predict leaves emission, and thus possible estimate crop performance, the phyllochron method might be used as a development model for Chicorium endivia. The use of air temperature as variable may be sufficient, considering that there are several elements and 
climatic factors that may influence development (Gramig \& Stoltenberg, 2007).

Thus, we determined $4.7^{\circ} \mathrm{C}$ the lower base temperature for Chicorium endivia growth, obtained through the values of 4.0 and $5.5^{\circ} \mathrm{C}$, observed in standard deviation in degree-days and regression coefficient methods. Chicorium endivia requires on average, from the emergency, accumulated thermal time of $1198.2^{\circ} \mathrm{C}$ day to reach harvest point. The linear regression method is efficient to estimate phyllochron in Chicorium endivia, showing 16.6 to $27.8^{\circ} \mathrm{C}$ day leaf ${ }^{-1}$.

\section{REFERENCES}

ALVARES, CA; STAPE, JL; SENTELHAS, PC; GONÇALVES, JLM; SPAROVEK, G. 2014. Köppen's climate classification map for Brazil. Meteorologische Zeitschrift 22: 711-728.

ARNOLD, CY. 1960. Maximum-minimum temperatures as a basis for computing heat units. American Society for Horticultural Science 76: 682-692.

ALLEN, RG; PEREIRA, LS; RAES, K; SMITH, M. 1998. Crop evapotranspiration - guidelins for computing grop water requirements. 1 . ed. Rome: FAO, 300p. (FAO Irrigation and Drainage Paper, 56).

BECKMANN-CAVALCANTE, MZ. 2009. Soluções nutritivas no desenvolvimento do crisântemo cultivado em vaso. Irriga 3: 205-219.

BIRCH, CJ; VOS, J; KINIRY, J; BOS, HJ; ELINGS, A. 1998. Phyllochron responds to acclimation to temperature and irradiance in maize. Field Crops Research, 59: 187-200.

BRUNINI, O; LISBÃO, RS; BERNAR-DI, JB; FORNASIER, JB; PEDRO JÚNIOR, MJ. 1976. Temperatura-base para alface cultivar "White Boston", em um sistema de unidades térmicas. Bragantia 5: 213-219.

CARON, BO; MANFRON, PA; LÚCIO, ADC; SCHMIDT, D; MEDEIROS, SLP; BONNECARRÈRE, RAG; DOURADO NETO, D. 2007. Equations to estimate shoot phytomass of lettuce. Ciência Rural 37: 1248-1254.

COCCO, KLT; SCHMIDT, D; CARON, BO; SOUZA, VQD; FONTANA, DC; PAULA, GMD. 2016. Estimated phyllochron in low tunnel cultivated strawberry cultivars. Ciência Rural 46: 1546-1552.

COMISSÃO DE QUÍMICA E FERTILIDADE DO SOLO - CQFSRS/SC. 2004. Manual de adubação e de calagem para os estados do Rio
Grande do Sul e Santa Catarina. 10. ed. Porto Alegre: SBCS/Núcleo Regional Sul.

DALMAGO, GA; FOCHESATTO, E; KOVALESKI, S; TAZZO, IF; BOLIS, LM; DA CUNHA, GR; NIED, AH; BERGAMASCHI, $H$;SANTI, A. 2013. Filocrono e número de folhas da canola em diferentes condições ambientais. Pesquisa Agropecuária Brasileira 48: 573-581.

DIAMANTE, MS; JÚNIOR, SS; INAGAKI, AM; SILVA, MB; DALLACORT, R. 2012. Produção e resistência ao pendoamento de alfaces tipo lisa cultivadas sob diferentes ambientes. Revista Ciência Agronômica 44: 133-140.

EMBRAPA. 2013. Sistema Brasileiro de Clasificação de Solos. 3. ed. Rio de Janeiro: EMBRAPA-SPI.

FAGUNDES, JD; STRECK, NA; STORCK, L; REINIGER, LRS. 2010. Base temperature and thermal accumulation of growth stages of Aspilia montevidensis. Bragantia 69: 499-507.

FELTRIM, AL; CECÍLIO FILHO, AB; REZENDE, BLA; BARBOSA, JC. 2006. Produção de chicória em função do período de cobertura com tecido de polipropileno. Horticultura Brasileira 24: 249-254.

FELTRIM, AL; CECÍLIO FILHO, AB; REZENDE, BLA; BARBOSA, JC. 2008. Growth and accumulation of macronutrients on chicory, covered or not with polypropylene. Horticultura Brasileira 26: 50-55.

FIGUEIREDO, EB; MALHEIROS, EB; BRAZ, LT. 2004. Interaction genotype $x$ environment of lettuce cultivars in Jaboticabal, Brazil. Horticultura Brasileira22: 66-71.

FILGUEIRA, FAR. 2000. Asteráceas. In: Manual de olericultura 3. ed. Viçosa: Editora UFV.

GRAMIG, GG; STOLTENBERG, DE. 2007. Leaf appearance base temperature and phyllochron for common grass and broadleaf weed species. Weed Technology. 21: 249-254.

ITOH, Y.; SANO, Y. 2006. Phyllochron dynamics under controlled environments in rice (Oryza sativa L.). Euphytica 150: 87-95.

ITOH, Y; SHIMIZU, H. 2012. Phyllochron dynamics during the course of late shoot development might be affected by reproductive development in rice (Oryza sativa). Development Genes and Evolution 222: 341-350.

MADARIAGA, F; KNOTT, J. 1951. Temperature summations in relation to lettuce growth. Proceedings of the American Society of Horticulture Science 58: 147-152.

MARTINS, FB; REIS, DF; PINHEIRO, MVM. 2012. Base temperature and phyllochron in two olive cultivars. Ciência Rural 42: 19751981.

MENDONÇA, HFC; CALVETE, EO; NIENOW, AA; COSTA, RCD; ZERBIELLI, L; BONAFÉ, M. 2012. Phyllochron estimation in intercropped strawberry and monocrop systems in a protected environment. Revista
Brasileira de Fruticultura 34: 15-23.

MONTEITH, JL. 1965. Evaporation and environment. In: SYMPOSIUM OF THE SOCIETY FOR EXPERIMENTAL BIOLOGY, 1965, New York. Anais... New York: The state and movement of water in living organisms. v.19, p.205-239.

MORENO, LS; PEDREIRA, CG; BOOTE, KJ; ALVES, RR. 2014. Base temperature determination of tropical Panicum spp. grasses and its effects on degree-day-based models. Agricultural and Forest Meteorology 186: 26-33.

PENMAN, ML. 1948. Evaporation: in introductory survey. Netherlands Journal of Agricultura Science 4: 9-29.

PRŽULJ, NM; MOMČILOVIĆ, VM. 2013. Effects of cultivar and year on leaf number in winter barley. Zbornik Matice srpske za prirodne nauke 125: 87-93.

REGHIN, MY; OTTO, RF; JACOBY, CFS; OLINIK, JR. 2006. Effect of tray types and cultivars on seedlings production and endive yield. Ciência e Agrotecnologia 30: 435-443.

REGHIN, MY; OTTO, RF; OLINIK, JR; JACOBY, CFS. 2007. Endive (Cichorium endivia L.) yield in function of tray types and seedlings age at transplanting.Ciencia e Agrotecnologia 31: 739-747.

ROSA, HT; WALTER, LC; STRECK, NA; ANDRIOLO, JL; SILVA, MRD; LANGNER, JA. 2011. Base temperature for leaf appearance and phyllochron of selected strawberry cultivars in a subtropical environment. Bragantia 70: 939-945.

SÁ, GD; REGHIN, M.Y. 2008. Desempenho de duas cultivares de chicória em três ambientes de cultivo. Ciência e Agrotecnologia 32: 378-384

SILVA, EL; MARTINEZ, LF; YITAYEW, M. 1999. Relationship between lettuce crop coeficient and growing degree days. Horticultura Brasileira 17:134-142

STRECK, NA; TIBOLA, T; LAGO, I; BURIOL, GA; HELDWEIN, AB; SCHNEIDER, FM; ZAGO, V. 2005. Estimating the plastochron in muskmelon (Cucumis melo L.) grown inside plastic greenhouse at different planting dates. Ciência Rural 35: 1275-1280.

SU, L.; WANG, Q.; BAI, Y. 2013. An analysis of yearly trends in growing degree days and the relationship between growing degree day values and reference evapotranspiration in Turpan area, China. Theoretical and Applied Climatology, 113: 711-724.

TAIZ, L; ZEIGER, E; MOLLER, IM; MURPHY, A. 2017. Fisiologia e desenvolvimento vegetal, $6^{\mathrm{a}}$ ed. Porto Alegre: Artmed. 858p.

VOLPE, CA; SCHÖFFEL, ER.; BARBOSA, JC. 2002. Influence of the accumulated heat unit and rainfall on the ratio and technological index of sweet oranges "Valência" and "Natal". Revista Brasileira de Fruticultura 24: 436-441. 